\title{
Rare and unexpected complication after a malpositioned nasogastric tube in a neonate
}

\author{
Osama Hosheh, Liz Mckechnie
}

Neonatal Unit, Leeds Teaching Hospitals NHS Trust, Leeds, UK

\section{Correspondence to \\ Dr Osama Hosheh,} drosama@hotmail.com

Accepted 6 April 2018

\section{DESCRIPTION}

A full-term newborn boy was admitted to the high dependency unit at the age of 4 hours with signs of respiratory distress, tachypnoea and recession with low oxygen saturation. There was no perinatal history of concerns; delivery was normal and uneventful, but the mother was colonised with Group B streptococcus.

A plan was made on admission for a chest X-ray, a nasogastric tube (NGT) insertion and antibiotics. NGT was placed by a senior neonatal nurse without incident, followed by chest X-ray primarily looking for respiratory causes of the respiratory distress. This however revealed that the NGT was malposed into the right main bronchus (figure 1). There were no signs of choking or cough at the time of insertion. NGT was then pulled out and a new one reinserted in a satisfactory position and confirmed on a repeat chest X-ray (figure 2). A right-sided small and simple pneumothorax was noted on the repeat chest X-ray; conservative management continued with supplemental oxygen via nasal cannula. The baby in our case however continued to have tachypnoea and grunting, with worsening blood gases over the next few hours. A follow-up chest X-ray was therefore obtained and showed extensive right-sided tension pneumothorax (figure 3). An emergency needle aspiration was performed in preparation for intubation and chest drain insertion. The baby was haemodynamically stable and tolerated the intubation well, but he required two further chest drains over the subsequent few days due to recurrent tension pneumothorax. A bronchopleural fistula was highly suspected due to the air bubbling through the water seal of the drainage device in synchrony with the inspiratory phase during ventilation. A cardiothoracic surgical referral

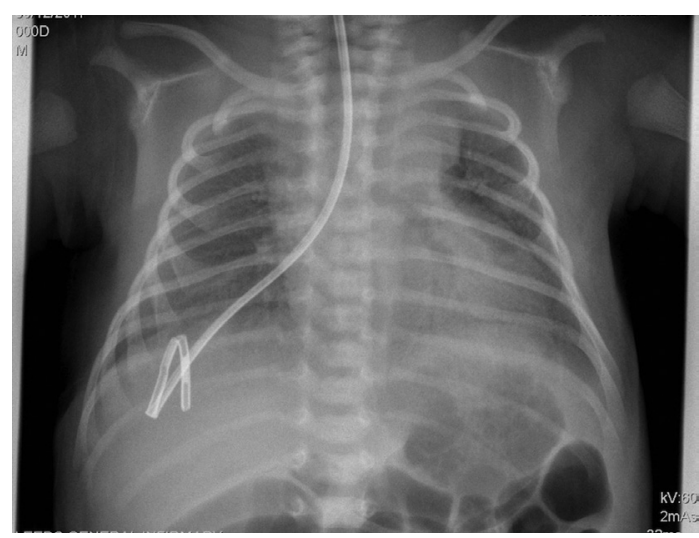

Figure 1 First $\mathrm{X}$-ray with nasogastric tube in the right main bronchus.

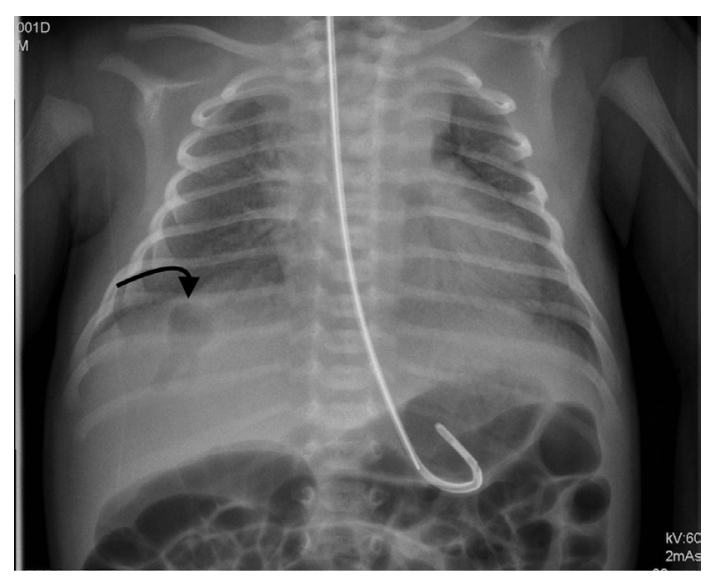

Figure 2 Repeat chest X-ray: a small right-sided pneumothorax in the right lower zone.

was averted as our baby made a good recovery afterwards. He stayed ventilated for a week and the last chest drain was successfully removed 2 days later. The baby was discharged home in good condition with neonatal follow-up appointment.

NGT blind insertion is a standard procedure for hospitalised patients done by qualified medical staff. Changes in policies, staff training and development of vigilant institutional protocols for NGT insertion have led to a substantial decrease in the number of complications following malpositioned NGT. Yet there is still a rare but considerable risk of complications arising from this procedure for which medical practitioners need to be aware of. ${ }^{1}$ A high index of suspicion for any clinical changes should therefore be maintained and promptly investigated. ${ }^{2}$

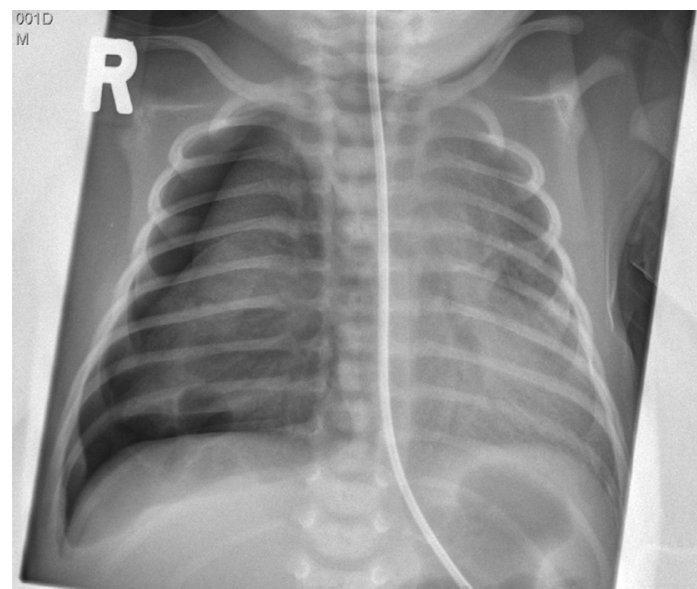

Figure 3 Right-sided tension pneumothorax. 


\section{Learning points}

Practitioners should be aware of the possible pulmonary complications associated with blind nasogastric tube (NGT) placement.

- A chest X-ray after the removal of a malpositioned NGT may be necessary to rule out lung injuries and bronchial complications.

Contributors $\mathrm{OH}$ has drafted the manuscript and LM was responsible for the final editing. $\mathrm{OH}$ and $\mathrm{LM}$ were involved in the clinical management of the patient and obtained the consent.
Funding The authors have not declared a specific grant for this research from any funding agency in the public, commercial or not-for-profit sectors.

Competing interests None declared.

Patient consent Parental/guardian consent obtained.

Provenance and peer review Not commissioned; externally peer reviewed.

(C) BMJ Publishing Group Ltd (unless otherwise stated in the text of the article)

2018. All rights reserved. No commercial use is permitted unless otherwise expressly granted.

\section{REFERENCES}

1 Sparks DA, Chase DM, Coughlin LM, et al. Pulmonary complications of 9931 narrowbore nasoenteric tubes during blind placement: a critical review. JPEN J Parenter Enteral Nutr 2011;35:625-9.

2 Paul V, Shenoy A, Kupfer Y, et al. Pneumothorax occurring after nasogastric tube removal. BMJ Case Rep 2013;2013:bcr2013010419.

Copyright 2018 BMJ Publishing Group. All rights reserved. For permission to reuse any of this content visit http://group.bmj.com/group/rights-licensing/permissions.

BMJ Case Report Fellows may re-use this article for personal use and teaching without any further permission.

Become a Fellow of BMJ Case Reports today and you can:

- Submit as many cases as you like

- Enjoy fast sympathetic peer review and rapid publication of accepted articles

- Access all the published articles

- Re-use any of the published material for personal use and teaching without further permission

For information on Institutional Fellowships contact consortiasales@bmjgroup.com

Visit casereports.bmj.com for more articles like this and to become a Fellow 